\title{
Antitumor effects and mechanisms of Ganoderma extracts and spores oil
}

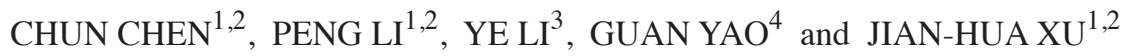 \\ ${ }^{1}$ School of Pharmacy; ${ }^{2}$ Fujian Key Laboratory of Natural Medicine Pharmacology, Fujian Medical University, \\ Fuzhou, Fujian 350108; ${ }^{3}$ Fujian Xianzhilou Biological Science and Technology Co., Ltd, Fuzhou, Fujian 350001, P.R. China; \\ ${ }^{4}$ Systems Biology Laboratory, Department of Molecular and Cellular Biology, University of Arizona, Tucson, AZ 85721, USA
}

Received April 4, 2016; Accepted June 29, 2016

DOI: $10.3892 / \mathrm{ol} .2016 .5059$

\begin{abstract}
Ganoderma lucidum is a popular herbal medicine used in China to promote health. Modern studies have disclosed that the active ingredients of Ganoderma can exhibit several effects, including antitumor effects and immunomodulation. The present study evaluated the antitumor effects of self-prepared Ganoderma extracts and spores oil, and investigated the possible underlying mechanisms by observing the effects of the extracts and oil on topoisomerases and the cell cycle. The results showed that Ganoderma extracts and spores oil presented dose-dependent inhibitory effects on tumor cells. The half maximal inhibitory concentration $\left(\mathrm{IC}_{50}\right)$ values of Ganoderma extracts on HL60, K562 and SGC-7901 cells for $24 \mathrm{~h}$ were $0.44,0.39$ and $0.90 \mathrm{mg} / \mathrm{ml}$, respectively; for Ganoderma spores oil, the $\mathrm{IC}_{50}$ values were 1.13, 2.27 and $6.29 \mathrm{mg} / \mathrm{ml}$, respectively. In the in vivo study, the inhibitory rates of Ganoderma extracts ( $4 \mathrm{~g} / \mathrm{kg} / \mathrm{d}$, intragastrically) on S180 and H22 cells were 39.1 and $44.6 \%$, respectively, and for Ganoderma spores oil (1.2 g/kg/d, intragastrically) the inhibitory rates were 30.9 and $44.9 \%$, respectively. Ganoderma extracts and spores oil inhibited the activities of topoisomerase I and II. Ganoderma spores oil was shown block the cell cycle at the transition between the $\mathrm{G} 1$ and $\mathrm{S}$ phases and induce a marked decrease in cyclin D1 levels in K562 cells, with no significant change in cyclin E level. These results suggest that the Ganoderma extracts and spores oil possessed antitumor effects in the in vitro and in vivo studies. The antitumor mechanisms of the extracts and spores oil were associated with inhibitory effects on topoisomerase I and II activities, and for Ganoderma spores oil, the antitumor effects may also be associated with decreased cyclin D1 levels, thus inducing G1 arrest in the cell cycle.
\end{abstract}

Correspondence to: Professor Jian-Hua Xu, School of Pharmacy, Fujian Medical University, 1 North Xuefu Road, Fuzhou, Fujian 350108, P.R. China

E-mail: xjh@fjmu.edu.cn

Key words: Ganoderma extracts, Ganoderma spores oil, tumor, topoisomerase I and II, cell cycle, cyclin D1

\section{Introduction}

Ganoderma lucidum, also called Ganoderma or Lingzhi, is one of most frequently used fungi in Chinese medicine. Modern pharmacological and clinical studies have confirmed that Ganoderma contains abundant biologically active substances in its fruiting body, mycelia and spores, and possesses variable functions, including immunomodulation, anti-aging, reducing blood lipids, anti-viral and anti-tumor activities (1-6). The present study examined the antitumor activity of a mixture of aqueous and ethanol extracts of the Ganoderma fruiting body and Ganoderma spores oil, which was extracted from broken spores by supercritical $\mathrm{CO}_{2}$ extraction technology and explored the possible underlying mechanisms. DNA topoisomerases are a class of enzymes involved in the regulation of DNA supercoiling. Topoisomerase overexpression has been linked to a number of human malignancies and is the target for numerous chemotherapeutic agents (7). In the event that topoisomerases are blocked, the cell encounters problems during transcription of the DNA and during cell division. The widely-used antitumor drug, campothecin, blocks the relaxing action of class I topoisomerases and induces significant G1 cell cycle arrest (8). A previous study indicated that the active components of Ganoderma exhibited inhibition of topoisomerases (9). The present study examined whether Ganoderma extracts and spore oil affected the cell cycle and topoisomerases I and II.

\section{Materials and methods}

Preparations of Ganoderma extracts and spores oil. Ganoderma extracts (GanoHerb ${ }^{\mathrm{TM}}$ ) and Ganoderma spores oil were provided by Fujian Xianzhilou Biological Science and Technology Co., Ltd. (Fuzhou, China). Ganoderma extract, a brown powder, was dissolved in double distilled water to prepare solutions of various concentrations, which were brown suspensions. Ganoderma spores oil was a soft capsule with $0.5 \mathrm{~g} / 0.5 \mathrm{ml}$ golden oil in each capsule. The stock solution of Ganoderma spores oil were prepared using double distilled water that contained $6 \mu 1 / \mathrm{ml}(\mathrm{v} / \mathrm{v})$ Tween 80 .

Cell lines and culture. The human acute myeloid leukemia HL-60, human chronic myeloid leukemia K562, human gastric carcinoma SGC7901, murine sarcoma S180 and murine 
hepatoma H22 cell lines were purchased from the Shanghai Cell Institute of the Chinese Academy of Sciences (Shanghai, China). All tumor cells were maintained in RPMI-1640 (Gibco; Thermo Fisher Scientific, Inc., Waltham, MA, USA) supplemented with $10 \%$ fetal calf serum (Hyclone; GE Healthcare Life Sciences, Logan, UT, USA) and antibiotics (100 kU/1 penicillin and $100 \mathrm{mg} / \mathrm{l}$ streptomycin) at $37^{\circ} \mathrm{C}$ in a humidified atmosphere of $5 \% \mathrm{CO}_{2}$.

\section{3-(4,5-dimethylthiazol-2-yl)-2,5-diphenyltetrazolium}

bromide (MTT) assay. The cell cytotoxicity of Ganoderma spores oil in vitro was detected by MTT assay. The MTT assay was based on the ability of live cells to utilize thiazolyl blue and convert it into dark blue formazan. Exponentially growing cells $\left(2 \times 10^{4} /\right.$ well) were seeded into 96 -well plates and treated with a series of concentrations of Ganoderma spores oil ( 0.31 , $0.63,1.25,2.5,5$ and $10 \mathrm{mg} / \mathrm{ml}$ ) for $24 \mathrm{~h}$. Control cells were exposed to double distilled water containing the same concentration of Tween 80. Subsequently, $20 \mu \mathrm{l}$ of $5 \mathrm{mg} / \mathrm{ml}$ MTT (Sigma-Aldrich, St. Louis, MO, USA) was added to each well and incubated for $4 \mathrm{~h}$. The dark blue formazan crystals were solubilized in lysis buffer containing $10 \%$ sodium dodecyl sulfate (SDS), 5\% isobutyl alcohol and $12 \mathrm{mmol} / 1 \mathrm{HCl}$, and the optical density (OD) was detected at $492 \mathrm{~nm}$ with a spectrophotometer. The rate of growth inhibition was calculated according to the formula: Inhibition rate $(\%)=(1-$ mean OD value of treated group/mean OD value of control group) x 100 . The half maximal inhibitory concentration $\left(\mathrm{IC}_{50}\right)$ value was calculated by linear regression method.

Trypan blue exclusion method. The cell cytotoxicity of Ganoderma extract in vitro was assessed using the trypan blue exclusion method. Briefly, exponentially growing cells were treated with a series of concentrations of Ganoderma extract $(0.22,0.44,0.67,0.89$ and $1.10 \mathrm{mg} / \mathrm{ml})$ for $24 \mathrm{~h}$. Control cells were exposed to double distilled water. Then cells were dyed with $0.4 \%$ trypan blue. Viable (trypan blue dye-excluding) cells were counted using a light microscope. Inhibition rate was calculated according to the formula: Inhibition rate $(\%)=(1-$ viable cells in treated group / viable cells in control group) x 100 .

Antitumor effects in vivo. A total of 60 ICR mice (6-8 weeks old; male and female; body weight, 18-20 g) were obtained from the Animal Centre of Fujian Medical University (Fuzhou, China) and maintained in specific pathogen-free conditions. Animals were exposed to a $12 \mathrm{~h}$ light/dark cycle and fed a standard diet. All animal studies were approved by the ethics committee of Fujian Medical University. S180 or H22 tumor cells in suspension ( $1 \times 10^{6}$ cells in $200 \mu$ l solution) were carefully inoculated intradermally into the left axilla of mice. The tumor-bearing mice were then randomly assigned to treatment experimental groups ( $\mathrm{n}=10$ per group). At $24 \mathrm{~h}$ following the tumor inoculation, mice were intragastrically administrated with i) extract of Ganoderma, $4 \mathrm{~g} / \mathrm{kg}$; ii) extract of Ganoderma, $2 \mathrm{~g} / \mathrm{kg}$; iii) extract of Ganoderma, $1 \mathrm{~g} / \mathrm{kg}$; iv) Ganoderma spores oil, $1.2 \mathrm{~g} / \mathrm{kg}$; v) fluorouracil (5-FU), $25 \mathrm{mg} / \mathrm{kg}$ (positive control); or vi) $0.9 \% \mathrm{NaCl}$ solution $0.2 \mathrm{ml} / 10 \mathrm{~g}$ (negative control) once per day for 10 consecutive days. At the end of the experiments (day 12), mice were weighed and then sacrificed by cervical dislocation. The tumors, thymus glands and spleens of the mice were excised carefully and weighed. The following formulae were used: i) Tumor suppression rate $(\%)=(1-$ mean tumor weight in treated group / mean tumor weight in control group) $\mathrm{x} 100$; ii) Thymus index $=100 \mathrm{x}$ thymus weight $/$ body weight; and iii) Spleen index $=100 \mathrm{x}$ spleen weight $/$ body weight.

Catalytic activity of topoisomerases. The catalytic activity of topoisomerases was measured as previously described (10). K562 cells $\left(10^{7}\right)$ were washed with phosphate-buffered saline (PBS) and treated with lysis buffer containing $20 \mathrm{mM}$ Tris, $1 \mathrm{mM}$ ethylene glycol-bis( $\beta$-aminoethyl ether)-N,N,N',N'-tetraacetic acid (EGTA), $25 \mathrm{mM} \mathrm{KCl,} 5 \mathrm{mM}$ $\mathrm{MgCl}_{2}, 250 \mathrm{mM}$ sucrose and $0.5 \% \mathrm{NP} 40$ (pH 7.2) for $10 \mathrm{~min}$ at $4^{\circ} \mathrm{C}$, then centrifuged at $4,000 \mathrm{x}$ g for $2 \mathrm{~min}$. The pellet was resuspended in $50 \mu \mathrm{l}$ of extraction buffer containing $20 \mathrm{mM}$ Tris, $1 \mathrm{mM}$ EGTA, $2 \mathrm{mM}$ ethylenediaminetetraacetic acid (EDTA), $2 \mathrm{mM}$ dithiothreitol (DTT) and $400 \mathrm{mM} \mathrm{NaCl}$ (pH 7.2) and incubated for $30 \mathrm{~min}$ at $4^{\circ} \mathrm{C}$. After centrifugation at $22,000 \mathrm{x}$ g for $15 \mathrm{~min}$, the supernatant containing extracted topoisomerases was obtained and its protein concentration was determined using the Bradford Protein Assay kit (Beyotime Institute of Biotechnology, Shanghai, China) according to the manufacturer's instructions, prior to storage at $-20^{\circ} \mathrm{C}$.

The catalytic activity of topoisomerase II in Ganoderma extracts was evaluated as follows: The total reaction volume was $10 \mu \mathrm{l}$, containing $2.5 \mu \mathrm{l} 4 \mathrm{X}$ reaction buffer [50 mM Tris (pH 8.0), $120 \mathrm{mM} \mathrm{KCl,} 0.5 \mathrm{mM}$ DTT, $0.5 \mathrm{mM}$ adenosine triphosphate (ATP), $10 \mathrm{mM} \mathrm{MgCl}_{2}$ and $30 \mu \mathrm{g} / \mathrm{ml}$ bovine serum albumin (BSA; Beyotime Institute of Biotechnology)], $0.1 \mathrm{mM}$ ATP (Promega Corporation, Madison, WI, USA), $0.2 \mu \mathrm{g}$ pBR322 DNA (Promega Corporation), various amounts of topoisomerase II-containing crude extract and double distilled water to make the total volume up to $10 \mu$ l. Following incubation at $37^{\circ} \mathrm{C}$ for $30 \mathrm{~min}$, the reaction was stopped by the addition of $5 \mu \mathrm{l}$ of a solution (50 mM EDTA, 50\% glycerol and $0.25 \mathrm{mg} / \mathrm{ml}$ bromphenol blue) maintained at $4^{\circ} \mathrm{C}$. Samples were separated through a $1 \%$ agarose gel. After staining with ethidium bromide, gels were photographed under ultraviolet (UV) illumination and analyzed using Syngene Genesnap Tools software (version 3.00.22; Syngene; Synoptics Ltd., Cambridge, UK).

The catalytic activity of topoisomerase I in Ganoderma extracts was evaluated as follows: The total reaction volume was $10 \mu \mathrm{l}$, containing $1 \mu \mathrm{l} 10 \mathrm{X}$ reaction buffer $[10 \mathrm{mM}$ Tris- $\mathrm{HCl}$ (pH 7.9), $0.15 \mathrm{M} \mathrm{NaCl}, 1 \mathrm{mM}$ EDTA, $0.1 \mathrm{mM}$ spermidine, $0.1 \%$ BSA and 5\% glycerol], $0.2 \mu \mathrm{g}$ pBR322 DNA, various amounts of topoisomerase I-containing crude extract and double distilled water to make the total volume up to $10 \mu 1$. The rest of the procedures were the same as the aforementioned topoisomerase II method.

The inhibitory effects of Ganoderma extracts and Ganoderma spores oil on topoisomerase I and II were then detected. After selecting the amounts of crude extract that unwound $0.2 \mu \mathrm{g}$ pBR322 DNA to establish topoisomerase I and topoisomerase II reaction systems, 1,2 and $4 \mathrm{mg} / \mathrm{ml}$ extracts and $4.5,9$ and $18 \mathrm{mg} / \mathrm{ml}$ spores oil was added to each reaction system and double distilled water was used to make the total volume up to $10 \mu \mathrm{l}$. Following incubation at $37^{\circ} \mathrm{C}$ for $30 \mathrm{~min}$, the reaction was stopped and separated through $1 \%$ agarose 
Table I. Growth inhibition rate of Ganoderma extracts on tumor cell lines.

\begin{tabular}{lcccccc}
\hline & \multicolumn{5}{c}{ Inhibitory rate, $\%$} & \\
\cline { 2 - 5 } Cell lines & $1.10 \mathrm{mg} / \mathrm{ml}$ & $0.89 \mathrm{mg} / \mathrm{ml}$ & $0.67 \mathrm{mg} / \mathrm{ml}$ & $0.44 \mathrm{mg} / \mathrm{ml}$ & $0.22 \mathrm{mg} / \mathrm{ml}$ & $\mathrm{IC}_{50,} \mathrm{mg} / \mathrm{ml}$ \\
\hline K562 & 97.34 & 90.55 & 85.71 & 40.48 & 9.52 & 0.44 \\
HL60 & 100.00 & 95.35 & 95.20 & 56.16 & 12.33 & 0.39 \\
SGC-7901 & 73.56 & 38.92 & 18.37 & 3.43 & -1.64 & 0.90 \\
\hline
\end{tabular}

$\mathrm{IC}_{50}$, half maximal inhibitory concentration.

Table II. Growth inhibition rate of Ganoderma spores oil on tumor cell lines.

\begin{tabular}{lccccccc}
\hline & \multicolumn{7}{c}{ Inhibitory rate, $\%$} \\
\cline { 2 - 6 } Cell lines & $10 \mathrm{mg} / \mathrm{ml}$ & $5 \mathrm{mg} / \mathrm{ml}$ & $2.5 \mathrm{mg} / \mathrm{ml}$ & $1.25 \mathrm{mg} / \mathrm{ml}$ & $0.63 \mathrm{mg} / \mathrm{ml}$ & $0.31 \mathrm{mg} / \mathrm{ml}$ & $\mathrm{IC}_{50}, \mathrm{mg} / \mathrm{ml}$ \\
\hline K562 & 83.14 & 74.47 & 70.21 & 52.63 & 32.31 & 11.49 & 1.13 \\
HL60 & 89.62 & 87.76 & 55.50 & 15.50 & 8.88 & 3.54 & 2.27 \\
SGC-7901 & 68.31 & 41.27 & 12.84 & 7.64 & -1.30 & 2.67 & 6.29 \\
\hline
\end{tabular}

$\mathrm{IC}_{50}$, half maximal inhibitory concentration.

gel. The staining gel was photographed under ultraviolet (UV) illumination and analyzed using Syngene Genesnap Tools software (version 3.00.22; Syngene).

Cell cycle analysis. The cell cycle was analyzed by flow cytometry. K562 cells were seeded in 6-well plates at a density of $1 \times 10^{5} / \mathrm{ml}$, and treated with 1.25 and $2.5 \mathrm{mg} / \mathrm{ml}$ Ganoderma spores oil for $12 \mathrm{~h}$. Then cells were washed twice with PBS and fixed in $70 \%$ ethanol at $4^{\circ} \mathrm{C}$ overnight. Prior to analysis, cells were washed and resuspended in PBS, then incubated with $10 \mathrm{mg} / \mathrm{ml} \mathrm{RNase}$ A for 3-5 min and $50 \mu \mathrm{g} / \mathrm{ml}$ propidium iodide (Sigma-Aldrich) at $4^{\circ} \mathrm{C}$ for $30 \mathrm{~min}$ in a dark chamber. The cell cycle distribution (percentage of cells in various phases) was analyzed by flow cytometry (Epics XL; Beckman Coulter, Inc., Brea, CA, USA) using Multicycle software (version 3.11; Phoenix Flow Systems; San Diego, CA, USA).

Western blot analysis. K562 cells $\left(1 \times 10^{7}\right)$ were washed with PBS and then treated with lysis buffer containing $50 \mathrm{mM}$ Tris- $\mathrm{HCl}$ ( $\mathrm{pH} 8.0$ ), $150 \mathrm{mM} \mathrm{NaCl}, 1 \mathrm{mM}$ phenylmethane sulfonyl fluoride, $1 \mathrm{mM}$ aprotitin and $1 \% \mathrm{NP} 40$ for $30 \mathrm{~min}$ at $4^{\circ} \mathrm{C}$. Following centrifugation at $11,000 \mathrm{x}$ g for $20 \mathrm{~min}$, the protein concentration of the supernatant was determined; equal amounts $(30 \mu \mathrm{g})$ of protein were separated by $10 \%$ SDS-polyacrylamide gel electrophoresis and then electro- transferred onto nitrocellulose membranes in transfer buffer. The membrane was blocked with $5 \%$ BSA for $2 \mathrm{~h}$ and then incubated with monoclonal mouse anti-human cyclin D1 (cat. no. sc-20044; 1:500), monoclonal mouse anti-human cyclin E (cat. no. sc-247; 1:500) and polyclonal rabbit anti-human actin (cat. no. sc-7210; 1:2,000) primary antibodies (Santa Cruz Biotechnology Inc., Dallas, TX, USA) in blocking solution at $4^{\circ} \mathrm{C}$ for $2 \mathrm{~h}$, followed by extensive washing with PBS twice. The membranes were then incubated with alkaline-phosphatase conjugated goat anti-mouse (cat. no. sc-2047; 1:2,500) and goat anti-rabbit (cat. no. sc-2034; 1:2,000) IgG secondary antibodies (Santa Cruz Biotechnology Inc.) in blocking solution at room temperature, followed by washing with Tris-buffered saline 3 times. The target proteins became visible following the addition of Alkaline Phosphatase Substrate Solution BCIP/NBT (Promega Corporation).

Statistical analysis. Statistical analysis of the data was performed with the Student's $t$-test. Data were expressed as the mean \pm standard deviation. $\mathrm{P}<0.05$ was considered to indicate a statistically significant difference.

\section{Results}

Inhibitory effects on tumor cells in vitro. The anti-proliferative activities of Ganoderma extracts and spores oil on the K562, HL60 and SGC-7901 cell lines were determined. Using the trypan blue exclusion method, dose-dependent inhibitory effects were observed when the Ganoderma extract concentrations were in the range of $0.22-1.10 \mathrm{mg} / \mathrm{ml}$. The $\mathrm{IC}_{50}$ value of Ganoderma extracts for the K562, HL60 and SGC-7901 cells were $0.44,0.39$ and $0.90 \mathrm{mg} / \mathrm{ml}$, respectively (Table I).

The MTT assays revealed that treatment with Ganoderma spores oil concentrations of $0.31-10.0 \mathrm{mg} / \mathrm{ml}$ caused dose-dependent cytotoxicity in K562, HL60 and SGC-7901 cells, with $\mathrm{IC}_{50}$ values of 1.13, 2.27 and $6.29 \mathrm{mg} / \mathrm{ml}$, respectively (Table II).

Suppression of tumor growth in vivo. The effects of intragastric administration of Ganoderma extracts and spores oil on S180 cells in mice were examined (Fig. 1; Table III). Table III shows that the $4 \mathrm{~g} / \mathrm{kg}$ extracts and $1.2 \mathrm{~g} / \mathrm{kg}$ oil groups resulted in significant inhibitions of tumor growth by comparing the average 
Table III. Inhibitory effects of Ganoderma extracts and spores oil on S180 in mice.

\begin{tabular}{lccccc}
\hline & \multicolumn{4}{c}{ Body weight, $\mathrm{g}$} \\
\cline { 2 - 4 } Groups $^{\mathrm{a}}$ & Start & End & Difference & Tumor weight, $\mathrm{g}$ & Inhibitory rate, \% \\
\hline Control & $21.1 \pm 1.3$ & $26.3 \pm 2.7$ & $5.2 \pm 1.7$ & $1.4 \pm 0.5$ & - \\
Extracts, $4 \mathrm{~g} / \mathrm{kg}$ & $21.6 \pm 1.2$ & $26.3 \pm 2.4$ & $4.7 \pm 1.8$ & $0.9 \pm 0.5$ & $39.1^{\mathrm{b}}$ \\
Extracts, $2 \mathrm{~g} / \mathrm{kg}$ & $21.6 \pm 0.7$ & $26.6 \pm 2.0$ & $5.0 \pm 1.8$ & $1.2 \pm 0.5$ & 19.0 \\
Extracts, $1 \mathrm{~g} / \mathrm{kg}$ & $21.6 \pm 0.7$ & $26.3 \pm 1.6$ & $4.7 \pm 1.6$ & $1.2 \pm 0.4$ & 15.6 \\
Oil, $1.2 \mathrm{~g} / \mathrm{kg}$ & $21.1 \pm 1.0$ & $25.9 \pm 2.3$ & $4.8 \pm 2.2$ & $1.0 \pm 0.4$ & $30.9^{\mathrm{b}}$ \\
5-FU, $25 \mathrm{mg} / \mathrm{kg}$ & $21.7 \pm 0.8$ & $22.0 \pm 2.6$ & $0.3 \pm 2.4^{\mathrm{c}}$ & $0.7 \pm 0.2$ & $54.1^{\mathrm{c}}$ \\
\hline
\end{tabular}

Data are expressed as mean \pm standard deviation. ${ }^{a}$ No. of mice per group $(\mathrm{n}=10) .{ }^{\mathrm{b}} \mathrm{P}<0.05,{ }^{\mathrm{c}} \mathrm{P}<0.01 \mathrm{vs}$. control; Student's $t$-test. 5-FU, fluorouracil .

\section{1: control}

2: Extracts $4 \mathrm{~g} / \mathrm{kg}$

3: Extracts $2 \mathrm{~g} / \mathrm{kg}$

4: Extracts $1 \mathrm{~g} / \mathrm{kg}$

5: Oil $1.2 \mathrm{~g} / \mathrm{kg}$

6: $5-\mathrm{FU} 25 \mathrm{mg} / \mathrm{kg}$

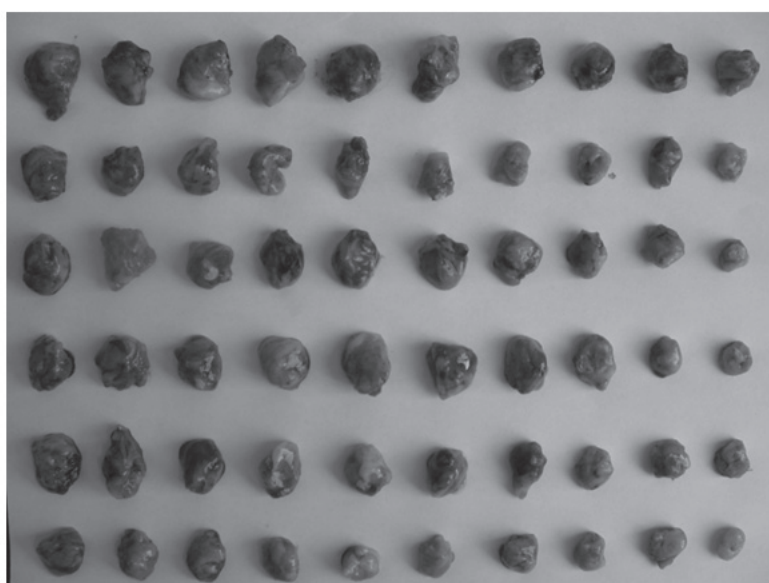

Figure 1. Tumor volume of S180 in mice influenced by Ganoderma extracts and spores oil. The tumor volumes in the $4 \mathrm{~g} / \mathrm{kg}$ extracts group and $1.2 \mathrm{~g} / \mathrm{kg}$ oil group were significantly smaller compared with the control group. 5-FU, fluorouracil.

\section{1: control \\ 2: Extracts $4 \mathrm{~g} / \mathrm{kg}$ \\ 3: Extracts $2 \mathrm{~g} / \mathrm{kg}$ \\ 4: Extracts $1 \mathrm{~g} / \mathrm{kg}$ \\ 5: Oil $1.2 \mathrm{~g} / \mathrm{kg}$ \\ 6: 5 -FU $25 \mathrm{mg} / \mathrm{kg}$}

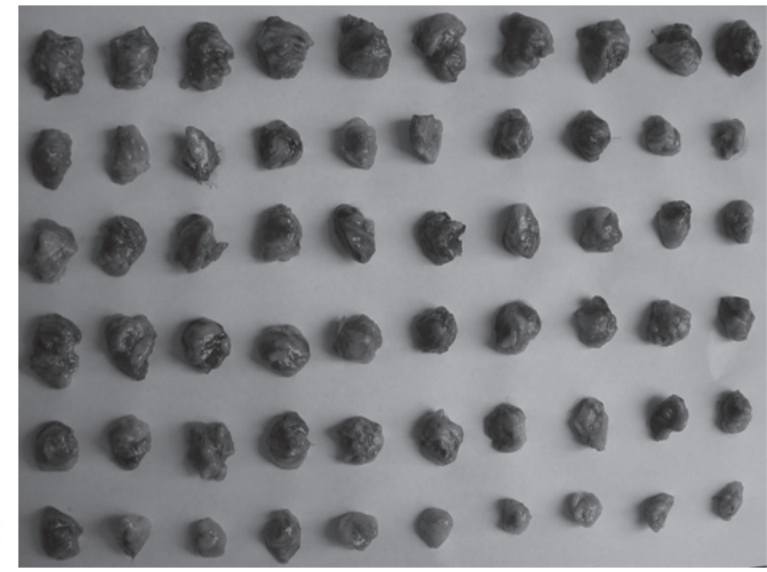

Figure 2. Tumor volume of $\mathrm{H} 22$ in mice affected by Ganoderma extracts and spores oil. All the Ganoderma extracts groups and the Ganoderma spores oil group exhibited potent inhibitory effects on $\mathrm{H} 22$ tumor volume. 5-FU, fluorouracil.

tumor weight with the control group at the end of the experiment $(\mathrm{P}=0.013$ and $\mathrm{P}=0.032$, respectively); however, the inhibitory rates of the 1 and $2 \mathrm{~g} / \mathrm{kg}$ extract groups were 15.6 and $19.0 \%$, respectively $(\mathrm{P}=0.253$ and $\mathrm{P}=0.170$, respectively). The average body weights were not significantly different among treatment groups, with the exception of the 5-FU group (positive control).
The suppressive effects of Ganoderma extracts and spores oil on H22 cells in mice are shown in Fig. 2 and Table IV. Data in Table IV showed that Ganoderma extracts and spores oil exhibited relatively strong inhibitory effects on $\mathrm{H} 22$ cells in mice. The inhibitory rates of the 1,2 and $4 \mathrm{~g} / \mathrm{kg}$ extract groups on $\mathrm{H} 22$ were $28.8,38.5$ and $44.6 \%$, respectively $(\mathrm{P}=0.008$, 
Table IV. Inhibitory effects of Ganoderma extracts and spores oil on H22 in mice.

\begin{tabular}{|c|c|c|c|c|c|}
\hline \multirow[b]{2}{*}{ Groups $^{\mathrm{a}}$} & \multicolumn{3}{|c|}{ Body weight, g } & \multirow[b]{2}{*}{ Tumor weight, g } & \multirow[b]{2}{*}{ Inhibitory rate, $\%$} \\
\hline & Start & End & Difference & & \\
\hline Control & $19.9 \pm 1.0$ & $29.8 \pm 1.6$ & $9.9 \pm 1.7$ & $2.0 \pm 0.4$ & - \\
\hline Extracts, $4 \mathrm{~g} / \mathrm{kg}$ & $19.6 \pm 1.2$ & $26.9 \pm 2.2$ & $7.3 \pm 1.7^{\mathrm{b}}$ & $1.1 \pm 0.2$ & $44.6^{c}$ \\
\hline Extracts, $2 \mathrm{~g} / \mathrm{kg}$ & $19.6 \pm 1.2$ & $29.2 \pm 3.4$ & $9.7 \pm 3.3$ & $1.2 \pm 0.3$ & $38.5^{\mathrm{c}}$ \\
\hline Extracts, $1 \mathrm{~g} / \mathrm{kg}$ & $19.3 \pm 0.7$ & $27.4 \pm 2.5$ & $8.1 \pm 2.5$ & $1.4 \pm 0.5$ & $28.8^{\mathrm{c}}$ \\
\hline Oil, $1.2 \mathrm{~g} / \mathrm{kg}$ & $19.5 \pm 1.2$ & $27.2 \pm 3.6$ & $7.8 \pm 2.8$ & $1.1 \pm 0.2$ & $44.9^{c}$ \\
\hline $5-\mathrm{FU}, 25 \mathrm{mg} / \mathrm{kg}$ & $19.1 \pm 1.1$ & $25.0 \pm 2.2$ & $5.9 \pm 2.1^{\mathrm{c}}$ & $0.7 \pm 0.2$ & $64.8^{c}$ \\
\hline
\end{tabular}

Data are expressed as mean \pm standard deviation. ${ }^{a}$ No. of mice per group $(\mathrm{n}=10) .{ }^{\mathrm{b}} \mathrm{P}<0.05,{ }^{\mathrm{c}} \mathrm{P}<0.01 \mathrm{vs}$. control; Student's $t$-test. 5-FU, fluorouracil.

Table V. Effect of Ganoderma extracts and Ganoderma spores oil on immunity indexes of mice bearing S180.

\begin{tabular}{lcc}
\hline Groups & Spleen index & Thymus index \\
\hline Control & $11.47 \pm 1.88$ & $2.13 \pm 0.59$ \\
Extracts, $4 \mathrm{~g} / \mathrm{kg}$ & $13.31 \pm 2.89$ & $2.79 \pm 0.67^{\mathrm{a}}$ \\
Extracts, $2 \mathrm{~g} / \mathrm{kg}$ & $13.17 \pm 3.69$ & $2.83 \pm 0.59^{\mathrm{a}}$ \\
Extracts, $1 \mathrm{~g} / \mathrm{kg}$ & $13.75 \pm 1.95^{\mathrm{a}}$ & $2.92 \pm 0.75^{\mathrm{a}}$ \\
Oil, $1.2 \mathrm{~g} / \mathrm{kg}$ & $12.29 \pm 2.55$ & $2.51 \pm 0.85$ \\
$5-\mathrm{FU}, 25 \mathrm{mg} / \mathrm{kg}$ & $10.57 \pm 3.74$ & $1.21 \pm 0.50^{\mathrm{b}}$ \\
\hline
\end{tabular}

Data are expressed as the mean \pm standard deviation. ${ }^{a} \mathrm{P}<0.05$, ${ }^{\mathrm{b}} \mathrm{P}<0.01$ vs. control; Student's $t$-test. 5-FU, fluorouracil.

Table VI. Effect of Ganoderma extracts and Ganoderma spores oil on immunity indexes of mice bearing $\mathrm{H} 22$.

\begin{tabular}{lcc}
\hline Groups & Spleen index & Thymus index \\
\hline Control & $13.67 \pm 2.89$ & $3.26 \pm 0.73$ \\
Extracts, $4 \mathrm{~g} / \mathrm{kg}$ & $16.48 \pm 4.25$ & $2.89 \pm 0.78$ \\
Extracts, $2 \mathrm{~g} / \mathrm{kg}$ & $15.39 \pm 3.78$ & $3.10 \pm 0.86$ \\
Extracts, $1 \mathrm{~g} / \mathrm{kg}$ & $14.25 \pm 3.84$ & $2.86 \pm 0.61$ \\
Oil, $1.2 \mathrm{~g} / \mathrm{kg}$ & $14.65 \pm 4.03$ & $2.60 \pm 0.78$ \\
$5-\mathrm{FU}, 25 \mathrm{mg} / \mathrm{kg}$ & $9.32 \pm 2.26^{\mathrm{a}}$ & $1.32 \pm 0.77^{\mathrm{b}}$ \\
\hline
\end{tabular}

Data are expressed as the mean \pm standard deviation. ${ }^{\mathrm{a}} \mathrm{P}<0.05$, ${ }^{\mathrm{b}} \mathrm{P}<0.01$ vs. control; Student's $t$-test. 5 -FU, fluorouracil.

Table VII. Effects of Ganoderma spores oil on K562 cell cycle.

\begin{tabular}{lcc}
\hline Groups $^{\mathrm{a}}$ & G1 phase, $\%$ & S phase, $\%$ \\
\hline Control & $32.7 \pm 0.5$ & $55.7 \pm 0.6$ \\
Oil, $1.25 \mathrm{mg} / \mathrm{ml}$ & $39.9 \pm 1.3$ & $42.3 \pm 0.2^{\mathrm{b}}$ \\
Oil, $2.5 \mathrm{mg} / \mathrm{ml}$ & $43.7 \pm 2.2^{\mathrm{b}}$ & $38.7 \pm 3.2^{\mathrm{b}}$ \\
\hline
\end{tabular}

Data are expressed as the mean \pm standard deviation. ${ }^{\mathrm{a}}$ No. of samples per group ( $\mathrm{n}=3)$. ${ }^{\mathrm{b}} \mathrm{P}<0.05$ vs. control; Student's $t$-test.
$\mathrm{P}=0.008$ and $\mathrm{P}=0.002$, respectively, compared with control group), and of the $1.2 \mathrm{~g} / \mathrm{kg}$ oil group was $44.9 \%(\mathrm{P}=0.004)$. The average body weights were significantly decreased in the $4 \mathrm{~g} / \mathrm{kg}$ extracts $(\mathrm{P}=0.038)$ and $5-\mathrm{FU}(\mathrm{P}=0.002)$ groups compared with the control group.

Effects on immunity indexes of mice bearing tumors. Table $\mathrm{V}$ shows that Ganoderma extracts increased the immunity indexes of mice bearing S180: The spleen index of the $1 \mathrm{~g} / \mathrm{kg}$ extracts group was significantly increased compared with the control group $(\mathrm{P}=0.041)$; the thymus indexes in the 1 , 2 and $4 \mathrm{~g} / \mathrm{kg}$ extracts groups were all improved significantly ( $\mathrm{P}=0.029, \mathrm{P}=0.021$ and $\mathrm{P}=0.038$, respectively); while in the 5 -FU group, the thymus index was decreased significantly $(\mathrm{P}=0.002)$. Ganoderma spores oil exerted no significant effects on spleen index and thymus index.

After treatment with Ganoderma extract and spores oil, there were no significant changes in the immunity indexes of mice bearing $\mathrm{H} 22$ cells (Table VI).

Inhibitory effects on topoisomerases activities. The activities of topoisomerase I and II are determined by the conversion of a fixed amount of supercoiled DNA into relaxed and broken DNA. Topoisomerase inhibitors could decrease the amount of relaxed and broken DNA and increased supercoiled DNA by inhibiting the catalytic activities of topoisomerases. The minimal concentration of crude topoisomerases from K562 cells required to fully relax $0.2 \mu \mathrm{g}$ pBR322 DNA was used to test Ganoderma extracts and spores oil.

The results showed that the Ganoderma extracts and spores oil inhibited the activities of topoisomerase I and II. Treated with Ganoderma extracts, $2 \mathrm{mg} / \mathrm{ml}$, topoisomerase I and II were inhibited, as reflected by the increased amount of supercoiled DNA and decreased amount of relaxed and broken DNA (Fig. 3). When Ganoderma spores oil, $4.5 \mathrm{mg} / \mathrm{ml}$, was added into the reaction system of topoisomerase I, supercoiled DNA was observed. As the concentration of Ganoderma spores oil was increased, the inhibition of topoisomerase in dose-dependent manner was observed. Using Ganoderma spores oil, $18 \mathrm{mg} / \mathrm{ml}$, the activity of topoisomerase II was then suppressed (Fig. 4).

Effect of Ganoderma spores oil on cell cycle. The cell cycle was analyzed by flow cytometry. As shown in Table VII, 


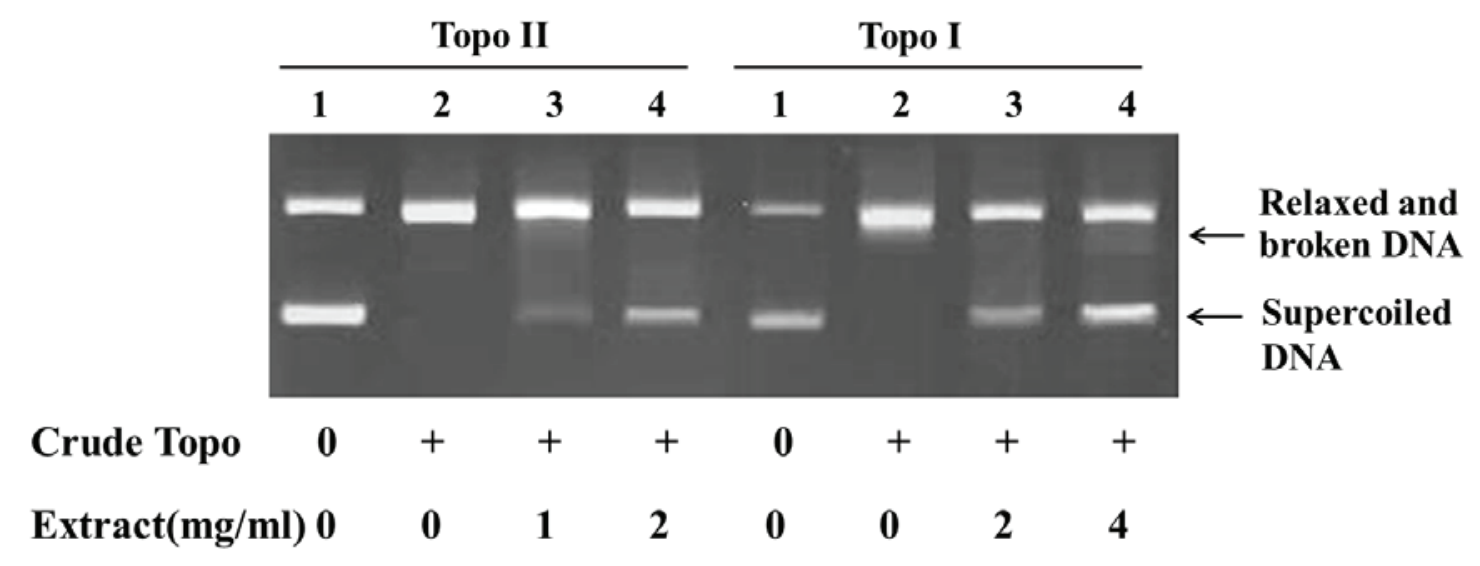

Figure 3. Effects of Ganoderma extracts on Topo I and II mediated pBR322 DNA relaxation. Ganoderma extracts showed inhibitory effects on Topo I and II at a dose of $2 \mathrm{mg} / \mathrm{ml}$. As dosage increased, $4 \mathrm{mg} / \mathrm{ml}$ extracts exhibited an even stronger effect on Topo I. Topo, topoisomerase.

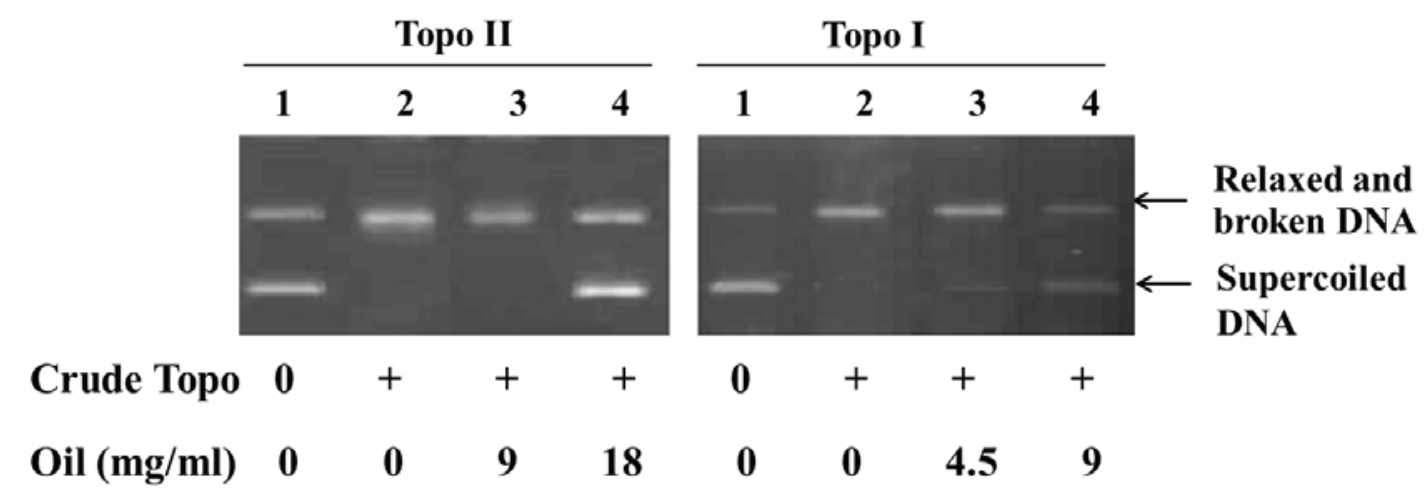

Figure 4. Effects of Ganoderma spores oil on Topo I and II mediated pBR322 DNA relaxation. Ganoderma spores oil showed a dose-dependent inhibitory effect on Topo I. At the dose of $18 \mathrm{mg} / \mathrm{ml}$, Topo II was also suppressed. Topo, topoisomerase.

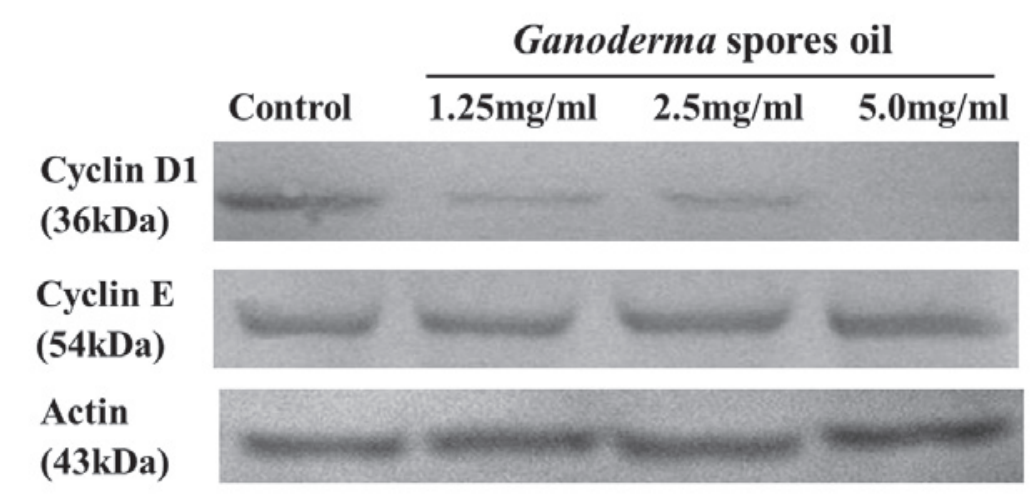

Figure 5. Level of cyclin D1 and E in K562 cells following treatment with various concentrations of Ganoderma spores oil for $12 \mathrm{~h}$. The level of cyclin D1 was downregulated by Ganoderma spores oil, $1.25-5.0 \mathrm{mg} / \mathrm{ml}$. Actin was used as a loading control.

Ganoderma spores oil induced a G1 arrest in K562 cells. With the treatment of Ganoderma spores oil, $1.25 \mathrm{mg} / \mathrm{ml}$, for $12 \mathrm{~h}$, the percentage of $\mathrm{S}$ cells in K562 was decreased from $55.7 \pm 0.6$ to $42.3 \pm 0.2(\mathrm{P}=0.038)$. When the concentration of Ganoderma spores oil was raised to $2.5 \mathrm{mg} / \mathrm{ml}$, the percentage of $\mathrm{S}$ cells was further decreased to $38.7 \pm 3.2$ $(\mathrm{P}=0.017)$, and the percentage of $\mathrm{G} 1$ cells rose from $32.7 \pm 0.5$ to $43.7 \pm 2.2(\mathrm{P}=0.022)$.
Results of Ganoderma spores oil on cyclin DI and cyclin E. Cyclin D1 and E are important regulators of G1-S phase cell cycle transition. The expression levels of cyclin D1 and $\mathrm{E}$ were determined by Western blotting. The results showed that after the treatment of Ganoderma spores oil $1.25-5.0 \mathrm{mg} / \mathrm{ml}$ for $12 \mathrm{~h}$, cyclin D1 expression in K562 decreased, but cyclin E expression exhibited no obvious change (Fig. 5). 


\section{Discussion}

Recently, the effect of Ganoderma on tumors has been increasingly studied. The present study revealed that Ganoderma extracts and spores oil inhibited the growth of human leukemia cells (K562 and HL60) and human gastric carcinoma cells (SGC-7901) in a dose-dependent manner. In addition, Ganoderma extracts and spores significantly suppressed the growth of the S180 and H22 transplant tumors in mice. Therefore, Ganoderma extracts and spores oil demonstrated definite antitumor effects in the in vitro and in vivo studies.

Since ancient times, Ganoderma has been widely used as a popular herbal medicine for the promotion of health (11). Numerous previous studies examined the immunomodulatory activities of Ganoderma $(12,13)$. By detecting the immunity indexes of mice bearing S180 or H22 cells, Ganoderma extracts were concluded to have a certain effect on improving immune function, while Ganoderma spores oil had no significant effect on the spleen or thymus indexes of mice. One of the main components of Ganoderma extract is a polysaccharide that has been reported as immune function enhancer (12-15). As there were few polysaccharides (water-soluble substances) in the Ganoderma spores oil, the spores oil exhibited no evident effect on immunity. The present study also indicated that the antitumor effects of Ganoderma may be safer compared with 5-FU, which resulted in the decreased body weight and immunity indexes of mice (Tables I and II).

To investigate the possible mechanism of Ganoderma extracts and spores oil, the effects of extracts and spores oil on topoisomerases and the effect of spores oil on the cell cycle were examined.

DNA topoisomerases are a class of enzymes involved in the regulation of DNA supercoiling. Type I topoisomerases change the degree of supercoiling of DNA by causing single-strand breaks and religation, whereas type II topoisomerases cause double-strand breaks. These two activities are particularly crucial during DNA transcription and replication, when the DNA helix must be unwound to allow proper function of large enzymatic machinery. Cancer chemotherapy takes advantage of this finding, using drugs that block topoisomerases to kill rapidly-dividing cancer cells. For instance, the widely-used anthracycline drugs, such as doxorubicin and daunorubicin, attack class II topoisomerases and the plant toxin, campothecin, blocks the relaxing action of class I topoisomerases (16).

Li et al (9) reported that Chinese Ganoderma lucidum essence, containing Ganoderma licidum extracted powder and sporoderm-broken spores powder, could inhibit the activities of topoisomerase I and II. Consistent with these reports, the results of the present study showed that the catalytic activities of topoisomerase I and II were inhibited by Ganoderma extracts and spores oil. This finding indicates that topoisomerase I and II may be target for the actions of Ganoderma extracts and spores oil.

Extracting Ganoderma spores oil from broken spores by supercritical $\mathrm{CO}_{2}$ extraction technology has been developed in recent years, and several studies have since examined the antitumor effect of Ganoderma spores oil $(17,18)$. In the present study, a G1 arrest was detected in K562 cells treated with Ganoderma spores oil. Ganoderma extracts are in a brown suspension and cannot be detected by flow cytometry.
Ganoderma spores oil mainly contains triterpenes and fatty acids, and Tang et al (19) reported that ganoderic acid T, a triterpenoid chemical, markedly inhibited the proliferation of a highly metastatic lung cancer cell line by apoptosis induction and cell cycle arrest at the G1 phase. Therefore, the cell cycle blocking effect of Ganoderma spores oil was assumed to mainly be associated with triterpenes.

To the best of our knowledge, the present study described, for first time, that the level of cyclin D1 decreased in Ganoderma spores oil-treated K562 cells. Cyclin D1 is critical for the G1-S transition of the cell cycle and induces G1 arrest when its level is too low. Therefore, a decrease in cyclin D1 levels may be suggested as one of the reasons for the G1 arrest of the K562 cell cycle, which resulted in the inhibition of cell growth in the presence of Ganoderma spores oil. The active substances in Ganoderma are worth studying further.

\section{Acknowledgements}

The authors gratefully acknowledge the Projects of International Science and Technology Cooperation from the Ministry of Science and Technology of China (grant no. 2013DFA30900) and the Projects of Industry-Academy Cooperation for Science and Technology of Fujian Province, China (grant no. 2016Y4005).

\section{References}

1. Kuo MC, Weng CY, Ha CL and Wu MJ: Ganoderma lucidum mycelia enhance innate immunity by activating NF-kappaB. J Ethnopharmacol 103: 217-222, 2006.

2. Lai CS, Yu MS, Yuen WH, So KF, Zee SY and Chang RC: Antagonizing beta-amyloid peptide neurotoxicity of the anti-aging fungus Ganoderma lucidum. Brain Res 1190: 215-224, 2008.

3. Hong KJ, Dunn DM, Shen CL and Pence BC: Effects of Ganoderma lucidum on apoptotic and anti-inflammatory function in HT-29 human colonic carcinoma cells. Phytother Res 18: 768-770, 2004.

4. Hajjaj H, Macé C, Roberts M, Niederberger P and Fay LB: Effect of 26-oxygenosterols from Ganoderma lucidum and their activity as cholesterol synthesis inhibitors. Appl Environ Microbiol 71: 3653-3658, 2005 .

5. Zhang W, Tao J, Yang X, Yang Z, Zhang L, Liu H, Wu K and Wu J: Antiviral effects of two Ganoderma lucidum triterpenoids against enterovirus 71 infection. Biochem Biophys Res Commun 449: 307-312, 2014

6. Loganathan J, Jiang J, Smith A, Jedinak A, Thyagarajan-Sahu A, Sandusky GE, Nakshatri H and Sliva D: The mushroom Ganoderma lucidum suppresses breast-to-lung cancer metastasis through the inhibition of pro-invasive genes. Int J Oncol 44: 2009-2015, 2014

7. Mariani A, Bartoli A, Atwal M, Lee KC, Austin CA and Rodriguez R: Differential targeting of human topoisomerase II isoforms with small molecules. J Med Chem 58: 4851-4856, 2015.

8. Wu N, Wu XW, Agama K, Pommier Y, Du J, Li D, Gu LQ, Huang ZS and An LK: A novel DNA topoisomerase I inhibitor with different mechanism from camptothecin induces $\mathrm{G} 2 / \mathrm{M}$ phase cell cycle arrest to K562 cells. Biochemistry 49: 10131-10136, 2010.

9. Li CH, Chen PY, Chang UM, Kan LS, Fang WH, Tsai KS and Lin SB: Ganoderic acid X, a lanostanoid triterpene, inhibits topoisomerases and induces apoptosis of cancer cells. Life Sci 77: 252-265, 2005.

10. Kruczynski A, Barret JM, Van Hille B, Chansard N, Astruc J, Menon Y, Duchier C, Créancier L and Hill BT: Decreased nucleotide excision repair activity and alterations of topoisomerase II alpha are associated with the in vivo resistance of a P388 leukemia subline to F11782, a novel catalytic inhibitor of topoisomerases I and II. Clin Cancer Res 10: 3156-3168, 2004 . 
11. Boh B, Berovic M, Zhang J and Zhi-Bin L: Ganoderma lucidum and its pharmaceutically active compounds. Biotechnol Annu Rev 13: 265-301, 2007.

12. Zhang S, Nie S, Huang D, Li W and Xie M: Immunomodulatory effect of Ganoderma atrum polysaccharide on CT26 tumor-bearing mice. Food Chem 136: 1213-1219, 2013.

13. Hsin IL, Ou CC, Wu TC, Jan MS, Wu MF, Chiu LY, Lue KH and Ko JL: GMI, an immunomodulatory protein from Ganoderma microsporum, induces autophagy in non-small cell lung cancer cells. Autophagy 7: 873-882, 2011.

14. Zhu XL and Lin ZB: Effects of Ganoderma lucidum polysaccharides on proliferation and cytotoxicity of cytokine-induced killer cells. Acta Pharmacol Sin 26: 1130-1137, 2005.

15. Gao Y, Gao H, Chan E, Tang W, Xu A, Yang H, Huang M, Lan J, Li X, Duan W, et al: Antitumor activity and underlying mechanisms of ganopoly, the refined polysaccharides extracted from Ganoderma lucidum, in mice. Immunol Invest 34: 171-198, 2005.
16. Hofland K, Petersen BO, Falck J, Helin K, Jensen PB and Sehested M: Differential cytotoxic pathways of topoisomerase I and II anticancer agents after overexpression of the E2F-1/DP-1 transcription factor complex. Clin Cancer Res 6: 1488-1497, 2000.

17. Peng X, Liu J, Xia J, Wang C, Li X, Deng Y, Bao N, Zhang Z and Qiu M: Lanostane triterpenoids from Ganoderma hainanense J. D. Zhao. Phytochemistry 114: 137-145, 2015.

18. Xu YN and Zhong JJ: Impacts of calcium signal transduction on the fermentation production of antitumor ganoderic acids by medicinal mushroom Ganoderma lucidum. Biotechnol Adv 30: 1301-1308, 2012.

19. Tang W, Liu JW, Zhao WM, Wei DZ and Zhong JJ: Ganoderic acid T from Ganoderma lucidum mycelia induces mitochondria mediated apoptosis in lung cancer cells. Life Sciences 80: 205-211, 2006. 